Silvia Parigi

Istituto Italiano per gli Studi Filosofici, Naples, Italy

ORCID: 0000-0001-9865-5774

e-mail: silpari@libero.it

\title{
The Scientific Background of Berkeley's Theory of Vision: Some Overlooked Berkeleian Sources
}

DOI: http://dx.doi.org/10.12775/RF.2019.056

It is a historiographical commonplace that George Berkeley was the founder of the empiristic theory of vision, on psychological bases: starting from his pioneering work, An Essay towards a New Theory of Vision (1709), optics became the science of vision. The standard question is following: was Berkeley's interests in the sciences authentic and genuine, that is to say, independent of his metaphysical principles and theological concerns? The traditional answer to this question is negative: Berkeley's deeper nature and authentic inclination were directed towards metaphysics, moral philosophy and theology. After all, in Bertrand Russell's words, "as he was at once a bishop and an Irishman, we ought not to be too hard on him."1

In order to reformulate and answer the previous question, it may be useful to start from another one: in the seventeenth and early eighteenth century, was there anybody who could be defined a scientist without being at the same time a metaphysician, a moral philosopher or a theologian? Since 1700, the year when he matriculated at Trinity College, Berkeley read philosophical works by Descartes, Hobbes, Gassendi, Locke, Molyneux, Newton, and Malebranche in which gnoseology,

1 Bertrand Russell, The Scientific Outlook (London: Allen \& Unwin, 1931), 82. The same thesis is maintained by Sébastien Charles, "Introduction", in: Science et épistémologie selon Berkeley, ed. Sébastien Charles (Saint-Nicolas, Québec: Les Presses de l’Université Laval, 2004): 1-8. 
metaphysics, optics, mathematics and philosophy of nature were deeply interwoven.

"When I wrote my Treatise about our System, I had an Eye upon such Principles as might work with considering Men, for the Belief of a Deity, and nothing can rejoice me more than to find it useful for that Purpose." ${ }^{2}$ The author of this bold declaration was not Berkeley, but Newton: nevertheless, just before quoting this passage, José Robles defines Newton and Boyle as "scientists", and Berkeley as a "philosopher". ${ }^{3}$

In Berkeley's times, "natural philosophy" covered a wide range of disciplines: from physics to chemistry, from astronomy to medicine and early speculations concerning electricity and magnetism; mathematics stands apart, until the great Newtonian synthesis. Optics was a branch of applied mathematics since Euclid; but, starting from Alhazen (ibn al-Haytham, 965-1040), it became a synonym of perspectiva, that is to say, a curious and complex discipline in which - in addition to the Euclidean doctrine of the geometrical properties of the rays of light - two other lines of thought had flown together: the medical tradition which had started from Galen and concerned the anatomy, physiology and pathology of the eye as well as the physical-psychological tradition which had started from Aristotle and concerned light, colours and visual perception.

Therefore, if we want to fully understand Berkeley's importance in the history of the sciences, he - as well as his fellow scholars - should be considered a "man of sciences", without worrying too much about his being a Bishop and the philosopher of esse est percipi in the meantime. That is to say, genuine and independent scientific commitment may have important relations with metaphysics and apologetics. Moreover, Berkeley's sources have to be singled out: they - as well as his fellow scholars' - were sometimes peregrine, uncommon, unfamiliar, forgotten, and quite inaccessible for us, if we do not share their wide erudition and deep knowledge of the past. ${ }^{4}$ But no theoretical synthesis is possible, or can be fully understood, without a preliminary historical analysis.

${ }^{2}$ Isaac Newton, letter to Richard Bentley, 10 December 1692, in: Isaac Newton's Papers \& Letters on Natural Philosophy, ed. I. B. Cohen (Cambridge, Mass.: Harvard University Press, 1958), 280.

3 José Antonio Robles, "Philosophie naturelle et religion: les cas de Newton, Boyle et Berkeley", in: Sebastien Charles, Science et épistémologie, 11-21.

${ }^{4}$ See Silvia Parigi, "Siris and the Renaissance: Some Overlooked Berkeleian Sources," Revue philosophique de la France et de l'étranger 1 (2010): 151-162 and idem, "'Scire per causas' versus 'scire per signa': George Berkeley and Scientific Explanation in Siris", in: George Berkeley. Religion and Science in the Age of Enlightenment, ed. Silvia Parigi (Dordrecht: Springer, 2010): 107-119. 
In this essay, the following theses will be argued:

a) Berkeley's interests in optics as a branch of science is authentic and original, regardless of his metaphysical and religious concerns. This theoretical attitude is quite common in the seventeenth and early eighteenth century: in fact, Berkeley shares this eclecticism with his main sources such as Descartes, Malebranche, Newton, Molyneux and Locke.

b) Berkeley gave important contributions to vision as a branch of science. A wide exploration of his sources, not limited to the most obvious and nearest ones, may cast further light on his scientific commitment and outcomes.

\section{Against Mathematicians}

Berkeley's most original and main theses are very well known: the immediate objects of vision are at no distance from us, in our eye, or mind; the alleged visual objects are indeed the tangible ones; there is an essential, constitutive heterogeneity between the objects of sight and touch. A chaotic, changing, two-dimensional "variety of light and colours," ${ }^{5}$ or "different proportions of light and shade" ${ }^{\prime}$ are the only real immediate objects of sight. They are signs whose meanings are the stable, coherent objects placed at a certain distance from us, endowed with determinate magnitudes and placed at some reciprocal situations. Those objects are not properly visual but tactile perceptions: they are the conclusion of "sudden judgements" suggested by some kinesthetic sensations such as the turn and strain of eyes by means of which we lessen or widen the interval between the pupils and prevent the confusedness of vision, ${ }^{7}$ or phenomenological data such as the greater or lesser "confusion or distinctness", "vigorousness or faintness" of the visual appearances.

An "innate geometry" cannot explain the process of vision as "optic writers" thought starting from Descartes' Dioptrique (1637). The link between visual clues and the alleged visual data - indeed, tactile objects in external space - is not a "necessary connection" or "geometrical necessity", but "experience and custom" or "habit": 8 therefore, visual perception is not immediate or innate. Nevertheless, we are not aware of learning visual language, because training in association between visual-kinesthetic sensations and tactile objects - whatever they really

\footnotetext{
NTV, 103.

${ }^{6} \mathrm{NTV}, 156$.

7 "This sensation belongeth properly to the sense of feeling" (TVV, 66).

8 NTV, 23-24; TVV, 20, 28.
} 
are-begins at the very moment of our birth and goes on constantly, with no interruption.

Where do these famous, shocking theses come from? What is the background from which they emerge? Berkeley's theory of vision is the outcome of the six-centuries long tradition of perspectiva, starting from Alhazen. ${ }^{9}$ His aim is to disentangle the whole matter:

To explain how the mind or soul of man simply sees is one thing, and belongs to philosophy. To consider particles as moving in certain lines, rays of light as refracted or reflected, or crossing, or including angles, is quite another thing, and appertaineth to geometry. To account for the sense of vision by the mechanism of the eye is a third thing, which appertaineth to anatomy and experiments. ${ }^{10}$

This a posteriori declaration of intents is decisive in order to comprehend Berkeley's theory of vision, as well as the choice of his antagonists: the "mathematicians", pretending to explain vision by "lines and angles" - the angle included within the optic axes, more or less diverging, being responsible for the perception of a lesser or a greater distance and magnitude. But: 1) lines and angles are mere hypotheses; they do not exist in rerum natura; 2 ) lines and angles are not themselves perceived; therefore, they cannot be the means through which we perceive objects in space: "brutes and children", as well as "grown reasonable men" never think of them, "whenever they perceive an object to approach, or depart from them",;13) even if lines and angles existed and were perceivable, they would fail to explain the true nature of vision, as the analysis of the main problems arising in its theory will definitely show.

Berkeley's NTV faces three main questions: the perception of the distance, magnitude and situation of bodies. From each of these problems one or more corollary questions stem Barrow's question - a puzzle concerning vision through biconvex lenses or concave glasses; the moon illusion, i. e. the greater appearance of the moon when it is on the horizon, in comparison with its zenithal magnitude; the role of the microscope in vision and minima visibilia; the "mighty difficulty" of the perception

9 For a history of the theories of visual perception, see A. I. Sabra, Theories of Light from Descartes to Newton (London: Oldbourne, 1967); Nicholas Pastore, Selective History of Theories of Visual Perception 1650-1950 (New York, London: Oxford University Press, 1971); David C. Lindberg, Theories of Vision from Al-Kindi to Kepler (Chicago and London: University of Chicago Press, 1976); Alistair C. Crombie, Science, Optics and Music in Medieval and Early Modern Thought (London: Hambledon Press, 1986); Revue d'histoire des sciences 1 (2007); for a survey of the history of the theories of visual perception, in connection with Berkeley's scientific background in optics, see Silvia Parigi, Il mondo visibile (Firenze: Olschki, 1995).

10 TVV, 43.

11 NTV, 24. 
of erect objects through inverted retinal images; Molyneux's famous problem concerning a man born blind, recovering sight, and asked to recognize the same objects - a cube and a sphere - which he used to perceive by touch.

Berkeley's most immediate source is Molyneux's Dioptrica nova (1692). ${ }^{12}$ This work is the last one in the long and glorious tradition of the treatises of perspective, all of them showing a similar structure: they begin with definitions of light and colours, even in mathematical terms. Next, they examine the anatomy of the eye, and finally, explain the ways in which direct, reflected and refracted vision is accomplished. It should be noted, once more, that there was no express distinction between the physical theories of light and colours, the physiology and the psychology of vision. Dioptrica nova was Berkeley's major source: Molyneux posed and analyzed those questions which Berkeley solved.

\section{The Perception of Distance and Magnitude}

Berkeley focuses on the second part of Dioptrica nova, which deals with direct vision and in which he can find the status quaestionum as to the main theoretical knots - all of which, in Berkeley's opinion, cannot be solved through geometrical explanations, but only require psychological arguments. The first question was posed by Isaac Barrow - Newton's predecessor on the Lucasian chair at Cambridge - in the last page of Lectiones opticae (1669): according to the Euclidean theory of locus objecti, an object seen through converging rays should appear very far from the eye, because "each visible point reflected by a mirror will appear at the intersection of the reflected ray with the perpendicular of incidence."13

But this is not true in the case of an object seen through a biconvex lens or a concave mirror: though those optical means make the rays coming to the eye converge the object is seen at the same, brief distance at which it would appear through the naked eye. This difficulty seems inexplicable in geometrical optics: André Tacquet, Pierre Sylvain Régis, Jacques Rohault, Francesco Maria Grimaldi ${ }^{14}$ - mathematicians and

${ }^{12}$ Margaret Atherton - in her Berkeley's Revolution in Vision (Ithaca and London: Cornell University Press, 1990) - does not acknowledge Molyneux's importance, limiting her historical analysis almost exclusively to Descartes and Malebranche. On the contrary, Jeffrey Barnouw stresses the close inspiration that Berkeley drew from Dioptrica nova: see his "The Two Motives Behind Berkeley's Expressly Unmotivated Signs: Sure Perception and Personal Providence", in: New Interpretations of Berkeley's Thought, ed. Steve H. Daniel (New York: Humanity Books, 2008): 145-177.

13 Euclid, Prospettiva (Firenze: Giunti, 1573): theor. XVIII.

14 André Tacquet, "Cataoptrica”, in: Opera matematica (Antuerpiae: I. Meursium, 1707): I, 22; Pierre Sylvain Regis, Système de philosophie (Lugduni: Anisson, Posuel 
Jesuits - failed in their tentative explanations and ended up considering such a question an exception confirming the rule. Both Barrow and Molyneux esteemed that problem insoluble "till a more intimate Knowledge of the Visive Faculty be obtained by Mortals". ${ }^{15}$

Berkeley, in fact, finds quite an easy solution, because he considers the confusion of the appearance, properly seen, as a sign of nearness. Visual judgements are not assimilable to mathematical conclusions: the Euclidean theorem, the laws of reflection and refraction, and the geometry of visual rays confirm their validity. Nevertheless, the eye does not make use of them in judging at what distance an object is; it perceives on the unique basis of past experience. In his Éléments de la philosophie de Newton (1738), Voltaire acknowledges Berkeley to have solved the question: "if nothing else could be objected, [this phenomenon] were alone sufficient to bring their [i.e. the geometrical theories of vision] credit in question." 16

The same conclusion might be adopted at the end of the discussion of the "celebrated phaenomenon"17 of the moon illusion: it is a psychological, not a mathematical question. The visual moon appears greateron the horizon than at the zenith; but the real - i.e. tangible - moon has the same extension; no astronomical instrument could measure such an increment. Berkeley's scheme of reasoning is the same: the faintness of the horizontal moon - due to the large portion of the interposed atmosphere, intercepting rays coming to the eye - is the decisive clue, suggesting a greater appearance to the mind. Moreover, the zenithal moon appears smaller because it is in an unusual position: above us, instead of being in front of us; therefore, the language of vision lacks its habitual signs, and we come to the wrong conclusion.

Once again, Berkeley could find a summary of the medieval and seventeenth-century discussion in an essay published by William Molyneux in the Philosophical Transactions, five years before Dioptrica nova. Molyneux confuted both the theories of the "mathematicians" - such as Alhazen, Witelo, Roger Bacon, John Pecham, Johannes Kepler, René Descartes, Honoré Fabri, Pierre-Sylvain Regis, André Tacquet, Thomas Hobbes, Nicolas Malebranche, Jacques Rohault, John Wallis - claiming that the optic angle was responsible for the moon illusion, and the physiological theory by Pierre Gassendi and Walter Charleton. They

\& Rigaud, 1691): VI, 8, 36; Jacques Rohault, Traité de physique (Venetiis: F. Pitteri, 1740, Latin edition; first edition 1671): 4-14; Francesco Maria Grimaldi, Physico-mathesis de lumine, coloribus et iride (Bononiae: ex typographia haeredis V. Benatii, 1665): I, 40, 72.

15 William Molyneux, Dioptrica Nova (London: B. Tooke, 1692), 115. See NTV, 29-40. On the scientific history of Barrow's question, see Silvia Parigi, "La 'quaestio' di Barrow: un'aporia della visione tramite lenti," Nuncius 3 (1988): 65-69.

16 NTV, 29.

17 NTV, 67. 
maintained that a larger retinal image, caused by the dilatation of pupil - due, in its turn, to the strain of perceiving a fainter appearance - was responsible for the increased appearance of the horizontal moon. As he had done in exposing Barrow's question, Molyneux himself abstained from any hypothesis. ${ }^{18}$

Berkeley's twofold solution of the moon illusion has no precedent in the seventeenth-century optics; nevertheless, both of them had been formulated, with striking similarity, by Ptolemy (II century after Christ), in Almagestum and Optics, respectively.

Magnitude of the stars appears larger at the horizon: not because of a lesser distance, but due to the earthly vapor exhaled between us and the stars; in the same way, submerged objects appear larger, - the more, as they become deeper. ${ }^{19}$

18 William Molyneux, "Concerning the Apparent Magnitude of the Sun and Moon, or the Apparent Distance of two Stars, when nigh the Horizon, and when Higher Elevated", Philosophical Transactions of the Royal Society of London 187 (1687): 314-323. See Pierre Gassendi, "Epistolae quatuor de apparente magnitudine Solis humilis et sublimis", in: Opera omnia (Stuttgart-Bad Cannstatt: Frommann, 1964, first edition 1727): vol. III, 420-477; Walter Charleton, Physiologia Epicuro-Gassendo-Charltoniana (New York-London: Johnson Reprint, 1966, first edition 1654): b. III, chap. III, 165; Alhazeni Arabis Opticae Thesaurus (New York-London: Johnson Reprint, 1972, first edition Basileae, 1572): b. II, XI, 39; Vitellionis Mathematici De natura, ratione et proiectione radiorum visus, luminum, colorum atque formarum, quam vulgo perspectivam vocant (Norimbergae: I. Petreium, 1535): b. IV, theor. XIII; Roger Bacon, "Perspectiva", in: The Opus Maius (Oxford: Clarendon Press, 1897): pt. II, chap. VI; John Pecham and the Science of Optics. Perspectiva communis, ed. David C. Lindberg (Madison, Milwaukee and London: The University of Wisconsin Press, 1970): pt. I, prop. 65; Johannes Kepler, „Paralipomena ad Vitellionem”, in: Gesammelte Werke (München: Becksche, 1938-1998): vol. II, chap. IX; René Descartes, Dioptrique, Discours VI, in: Oeuvres de Descartes (Paris: Vrin, 1964-1974): vol. VI (hereafter AT); Rohault, Traité de physique, vol. I, chap. XXXII, 24; Honoré Fabri, Synopsis optica (Lugduni: H. Boissat \& G, Remens, 1667): prop. VII, LV; Regis, Système de philosophie, vol. VI, b. VIII, pt. II, chap. 32; Tacquet, Optica, b. I, prop. XXX; Thomas Hobbes, De corpore, pt. IV, in: Opera latina (Londini: J. Bohn, 1839; Second Reprint Scientia Verlag Aalen, 1966): vol. I, 376-377; Malebranche, Recherce de la vérité, b. I, chap. VI, and Réponse à Monsieur Regis, in Oeuvres (Paris: Vrin, 1962-1970): vol. I and XVII-1, chap. I, 263-279; John Wallis, "The Sentiments of the Reverend and Learned Dr. John Wallis upon the Aforesaid Appearance, communicated in a Letter to the Publisher", Philosophical Transactions of the Royal Society of London 187 (1687): 323-329. For the history of the moon illusion, from the Middle Ages to the twentieth century, and the relevance of Berkeley's doctrine, see Silvia Parigi, "George Berkeley e l'illusione lunare", Rivista di storia della scienza 4 (1987): 51-60; see also David Berman, "Berkeley and the Moon Illusions," Revue Internationale de Philosophie 39 (1985): 215-222.

19 "Nam quod juxta horizontem major magnitudo stellarum videatur, non distantiae parvitas id facit, sed hujusmodi terra obeuntis evaporatio quum inter visum nostrum et stellas ipsas exhalet, veluti majora in aquis submersa videntur, et quidem 
And:

When the visible ray falls on things in an unusual way, it is less sensible of all their differences; also its precision in catching their distances decreases. Therefore, among celestial bodies, those which subtend equal angles between the visual rays and are nearest to that point, placed right over our head, appear smaller; while those which are at the horizon, are seen in the usual way. In fact, the highest things appear unusually the smallest, because of the difficult way in which they stand before our eyes. $^{20}$

Did Berkeley know those passages? Did he ever read works by Ptolemy when he was a student and then a lecturer in Greek at Trinity College? It seems quite probable: in the catalogue of Berkeley's library common to his son and grandson' $\mathrm{s}^{21}$ - Ptolemy is present, as well as the Neoplatonic tradition in its whole. Surely Plotinus' Enneads - often quoted in the Siris - is another important, though neglected, source of not only immaterialism - for the famous conception of matter as not-being but also of his theory of vision. In that work, Berkeley could find both a criticism of visual angle as a means of the perception of magnitude, ${ }^{22}$ and the doctrine of the tangible nature of magnitude according to which "visible size appears as the primary object of touch." ${ }^{23}$

A further question concerning the continuous or discrete nature of the visible objects stems from the discussion of the visual perception of magnitude ${ }^{24}$ in order to solve it, Berkeley introduces a comparison between the "microscopic" and the naked-eye vision. He constantly tries to

tanto majora, quanto profundiora petierint": see Claudius Ptolemaeus, Almagestum (Venetiis: P. Lichtenstein, 1515), 33. Translation mine.

20 "Universaliter enim cum visibilis radius, quando cadit super res videndas aliter quam inest ei de natura et consuetudine, minus sentit omnes diversitates quae in eis sunt, similariter etiam erit sensibilitas eius de distantiis, quas comprehendit, minor. Videntur autem hac de causa quod de rebus quae sunt in coelo, et subtendunt aequales angulos inter radios visibiles, illae quae propinquae sunt puncto, qui super caput nostrum est, apparent minores; quae vero sunt prope horizontem, videntur diverso modo et secundum consuetudinem. Res autem sublimes videntur parvae extra consuetudinem et cum difficultate actionis secundum id quod praetexavimus"; see Claudius Ptolemaeus, Ottica (Torino: Paravia, 1855): b. II, 77-78; see also 51-52, 58. Translation mine.

21 "A Catalogue of the valuable Library of the late Right Reverend Dr. Berkeley, Lord Bishop of Cloyne. Together with the Libraries of his Son and Grandson (London: Leigh \& Sotheby, 1796)", in: George Berkeley. Eighteenth-Century Responses, ed. David Berman (New York-London: Garland, 1989): vol. II, 469-516.

22 Plotinus, Enneads, II, 8, 2.

${ }^{23}$ Plotinus, Enneads, II, 8, 1 .

${ }^{24} \mathrm{NTV}, 56,59$. 
distinguish ${ }^{25}$ "visible objects" (also called appearances) both from retinal images (no optic writers, from the medievals up to Descartes and Gassendi, had done this) and from tangible things. A perceivable extension both visual and tangible - is not infinitely divisible; it consists of minima sensibilia i.e. visible or tangible points: we know it with an empirical, absolute certainty.

In fact, whatever may be said of extension in abstract, sensible extension is not infinitely divisible: there are a Minimum Tangibile and a Minimun Visibile, beyond which the sense cannot perceive. ${ }^{26}$ The existence of minima sensibilia is an empirical, psychological, phenomenal truth: it is a matter of fact, not a mathematical hypothesis; infinite divisibility may only concern the alleged abstract idea of extension, if it exists, and is the object of geometry. Berkeley underlines, once more, that immediately visible objects are not the objects that we usually think to see, i. e. objects of a certain, measurable extension and figure, placed at a certain, measurable distance from us: there is an irreducible heterogeneity between the coach heard "driving along the street", the coach seen "looking through the casement" and the coach to which "walk out and enter." 27

Given the discrete nature of visible objects, each minimum visibile has two properties: 1) it is the same in all sentient beings, regardless of their size, in an insect or in a man, because it is a phenomenal atom or point, without any part; 2 ) the Sphaera Visualis, ${ }^{28}$ or visual field, always contains the same number of minima, in the most open view as well as inside a narrow room because "any visible point can cover or exclude from view only one other visible point." ${ }^{29}$

Though our sight is structurally limited both in extension and distinctness, it is perfectly fit for practical purposes, thanks to its usual association with touch; the microscope - one of the most celebrated scientific discoveries in Berkeley's times - is not able to remedy those two constitutive imperfections: it cannot enlarge our visual field, or increase visual acuity. It only brings us into a new world, ${ }^{30}$ that is not the real world: it unfolds before our eyes a "new scene of visible objects", which lacks any association with the tactile, external objects. Therefore, the "microscopic" look would not only be useless from a theoretical point of view, because it would not show us the true structure of matter; it would also be dangerous from the point of view of our survival in a world made of tangible objects at a certain distance from us whose approach and im-

\footnotetext{
25 Though not always successfully: see, for example, NTV, 60, 73.

${ }^{26}$ NTV, 54.

27 NTV, 46.

28 This term is only present in NB, 169, 256.

${ }^{29}$ NTV, 79.

${ }^{30} \mathrm{NTV}, 85$.
} 
pact with our bodies might be "hurtful and destructive." 31 In the end, we must admit that "in the contrivance of vision, as in that of other things, the wisdom of Providence seemeth to have consulted the operation, rather than the theory, of man." 32

The opinion of the practical uselessness of microscopes was shared by such different authors as John Locke - a mistrustful empiricist - and Richard Bentley, a confident apologist: both of them were convinced of the reliability of the human senses for the purposes of everyday life, in praise of God's wisdom and providence; so was Berkeley. ${ }^{33}$

However, Berkeley's intention, once more, is not to undervalue or diminish the importance of the microscope as a scientific instrument; it can open a "new scene" before the natural philosopher's eye, whose inquiry may add new chapters to the grammar of nature. But we must never forget that nature is the realm of the second causes, to use the language of Siris.

Berkeley knew the early microscopists' works: in the catalogue of his library, there are Marcello Malpighi, Giovanni Alfonso Borelli and Francesco Redi's pioneering works; but his most important sources were Robert Hooke, a leading figure in the "mechanical philosophy"; William Molyneux - who reports the dispute between Hooke and Hevelius on the usefulness of the optical instruments - and the "mathematician" Isaac Barrow. From an epistemological point of view, Malebranche and Locke had stressed the abyss separating the secondary from the primary qualities of bodies - or visible perceptions from the tactile ones, in Berkeley's terms. In Hooke, Berkeley could also find the measurement of the perceptive threshold, fixed in a minute of angle; this is a "sensible point", according to Locke; ${ }^{34}$ Berkeley fixes the diameter of the visible moon in thirty visible points ${ }^{35}$ bearing in mind that the proper, astronomical definition of the visible point - introduced in order to measure the degree of obscuration in an eclipse - is the twenty-fourth part of the diameter of the Sun or the Moon.

31 NTV, 147.

32 TVV, 36.

33 See NTV, 87. John Locke, Essay, II, XXIII, 12-13; Richard Bentley, Boyle Lectures, 1692: see Marjorie Nicolson, Science and Imagination (Ithaca-New York: Great Seals Book, 1962); Henri Guerlac, "Bentley, Newton and Providence: The Boyle Lectures Once More", Journal of the History of Ideas 30 (1969): 307-318. For the mistrustful attitude of the empiricists towards the microscope, see Catherine Wilson, "Visual Surface and Visual Symbol: the Microscope and the Occult in Early Modern Science," Journal of the History of Ideas 49 (1988): 85-108. On the history of the epistemological conceptions of the microscope in the seventeenth century, see also Silvia Parigi, "I filosofi e il microscopio; da Descartes a Berkeley". Rivista di storia della scienza 1 (1993): 155-172.

${ }^{34}$ Essay, II, XV, 9.

35 NTV, 44. 
Berkeley's doctrine of the sensible - visible and tangible - minima is explored to a certain length in $\mathrm{NB}^{3}{ }^{36}$ it is mainly dealt with in NTV, and completely abandoned after PHK, probably because of the simultaneous neglect of his geometrical projects. ${ }^{37}$

\section{The "Knot about Inverted Images"}

There is a "mighty difficulty" that Berkeley goes on investigating through his youth works, up to TVV: the "knot about inverted images", which he always considers "the principal point in the whole optic theory", able to let us apprehend "the true nature of vision." 38 Why are retinal images so important for visual perception? The answer lays in the history of optics: starting from Galen and Alhazen, the crystalline lens had been considered the proper seat of vision: each point in the visible object emits rays in all directions (species radiosae quasi infinita ${ }^{39}$ ), but the eye can only perceive the perpendicular ones. The outcome is a visual pyramid with its base on the object, and its vertex in the centre of the crystalline lens supposed to coincide with the centre of the whole eye; therefore, in the absence of any refraction, the picture is erect, and remains in that way, when it comes to the cerebral ultimum sentiens or sensus communis in the optic chiasma, at the end of its journey through the vitreous humour and the optic nerves.

In Paralipomena ad Vitellionem (1604), Johannes Kepler - in spite of a still imperfect anatomical description of the eye, with a spherical

${ }^{36}$ See, for example, $61,88,116,169,256,273,277,287,321,345,439,441,442,749$, 835.

${ }^{37}$ This project had been exposed in NTV, 160: this paragraph was present only in the first two editions of that work. See also NB, 249, 250, 258, 264, 267, 395, 469, 470, 471, 500, 525; PHK, 130-132.

38 TVV, 52; NTV, $88 \mathrm{ff}$.

39 Roger Bacon, "Tractatus de multiplicatione specierum", in: Perspectiva, pt. II, chap. I, 458. This theory goes back to Al-Kindī (IX cent.), "De radiis", Archives d'histoire doctrinale et littéraire du Moyen Age 41 (1974; but 1975): 139-260. See Franco Alessio, "Per uno studio sull'ottica del Trecent", Studi medievali 3 (1961): 444-504; David C. Lindberg, "The Theory of Pinhole Images from Antiquity to the Thirteenth Century", Archive for the History of the Exact Sciences 5 (1968): 154-176; Theories of Vision from Al-Kindi to Kepler; "The Science of Optics", in: Science in the Middle Ages, ed. David C. Lindberg (Chicago and London: University of Chicago Press, 1978): 338-368; Studies in the History of Medieval Optics (London: Variorum Reprints, 1983); "Roger Bacon and the Origin of Perspectiva in the West", in: Mathematics and Its Applications to Science and Natural Philosophy in the Middle Ages, ed. Edward Grant and John E. Murdoch (Cambridge: Cambridge University Press, 1987): 249-268; Alistair C. Crombie, "Expectation, Modelling and Assent in the History of Optics: Part I. Alhazen and the Medieval Tradition", Studies in the History and Philosophy of Science 21 (1990): 605-632. 
crystalline lens and the optic nerves ending up just in its centre, in the absence of a correct law of refraction - tracks the path of the rays of light through the crystalline lens, up to the obscure fund of the eye, and clearly denounces the paradox of inverted retinal images as the means, or proximate cause, of the vision of erect objects..$^{40}$ Before Kepler, the Swiss physician Felix Plater attributed a new role to the retina: not the nourishment of the vitreous humour, as the authors of perspective had traditionally stated, but the proper organ of vision. Nevertheless, in his seminal work, known to Kepler, De corporis humani structura et usu (1583), he shows no interest in the visual pictures. The Keplerian theory of the double cone of rays - with the vertexes on each object's point and the corresponding retinal point, and the common base on the crystalline lens - is, at the same time, geometrical, physical and physiological. In fact, Kepler is convinced that retinal pictures are able to affect, and be directly perceived by the sensus communis ("haec pictura seu illustratio est passio aliqua"); ${ }^{41}$ but he is not willing to face the problem of the way in which vision is accomplished through them.

After him, optic writers generally adopted the geometrical explanation: starting from an Austrian Jesuit, Christoph Scheiner, whose Oculus: hoc est, fundamentum opticum (1619) contains the first correct anatomical description of the eye - all of them limited themselves to trace back the optic rays, from the retinal points up to the points of the object emitting them, thus "straightening" the inverted retinal images. "Mathematicians", such as Grimaldi, Fabri, Barrow, Rohault and Regis, as well as physicians, for instance Charleton, shared this simple solution. ${ }^{42}$

However, according to Berkeley, optic rays are never felt, nor are retinal images: therefore, vision cannot be explained through them. In TVV, Berkeley denounces the "vulgar error" of believing that retinal images may be felt: ${ }^{43}$ not only Kepler but also Locke ${ }^{44}$ had fallen into such a misunderstanding. As to his own solutions, Berkeley shows his usual debt towards Molyneux, who first highlighted the linguistic nature of the

${ }^{40}$ Johannes Kepler, "Paralipomena ad Vitellionem", chap. V, 3, in: Gesammelte Werke, vol. II. The law of refraction was correctly formulated by Wilibrod Snell in 1621, and first enounced by Descartes in Dioptrique (1637): see Crombie, "La Dioptrique et Kepler" and "Expectation, Modelling and Assent in the History of Optics: II. Kepler and Descartes"; William R. Shea, The Magic of Number and Motion (Canton Mass.: Science History Publications, 1991).

${ }^{41}$ Kepler, "Dioptrice" (1611), in: Gesammelte Werke, vol. IV, prop. LXI, 372.

${ }^{42}$ For the history of this "mighty difficulty", from the Middle Ages up to the twentieth century, see Bruce S. Eastwood, "Alhazen, Leonardo, and Late-Medieval Speculation on the Inversion of Images in the Eye", Annals of Science 43 (1986): 413-446; Silvia Parigi, "L'occhio e la camera oscura: storia dell'abbandono di una metafora," Iride 3 (1989): 91-109.

${ }^{43} \mathrm{TVV}, 50$. See also NB, 274, where this opinion is defined a "strange errour".

44 Essay, II, IX, 8-10. 
"knot" in a printed work: the words "erect" and "inverted" are relative terms, linked to "up" and "down", "farer from" or "nearer to" the centre of the earth. The first to find this solution was Newton in his youthful, unpublished Trinity Notebook: retinal images are judged inverted only after a comparison with external objects. ${ }^{45}$

But Molyneux does not draw any psychological inference from his premises: he concludes, in a usual way, that the eye is able to follow back the crossing rays, in order to recover the correctness of vision. On the contrary, Berkeley sticks to the psychological way, and makes a decisive use both of the heterogeneity assumption and the experimentum crucis of the blind man recovering sight. First of all, the two-dimensionality of the visual field is not geometrical. ${ }^{46}$ Therefore, it is not possible to distinguish any direction, any unit in it: "up" and "down", "right" and "left" - as well as perceptual units - have only a tactile meaning. A "virgin", inexperienced eye could only perceive a chaos of light, shadows and colors, inside which it would not be able to isolate such things as "one head", "two feet", nor perhaps even a man. A numerical and directional order is introduced in the visual field through the association of the kinesthetic-tactile sensations of the movements of the eyes, the head and the hands, which let us experience some constant and regular changes in our visual chaos.

Secondly, retinal pictures themselves are not inverted; they are judged in that position, only if compared with tangible, external objects. In TVV, Berkeley is more precise: retinal images are not visible ideas, unless they are perceived on the fund of another eye. But in this case, they are tactile objects, like every other thing outside us: "tangible figures projected by tangible rays on a tangible retina." 47

It has never been pointed out that the case of a man looking at the retinal images on the fund of another eye - as well as a man born blind recovering sight - was not an imaginary experiment, in Berkeley's times. ${ }^{48}$ Leonardo da Vinci had probably been the first to hypothesize such a case, as one of his drawings unequivocally shows; ${ }^{49}$ Kepler theorized it; $^{50}$ in 1609, Scheiner first made such an experiment, opening a window in the sclera and choroid coats of the eye of an ox, and looking at the retinal images. Descartes first published that anatomical experience having

${ }^{45}$ Isaac Newton, Certain Philosophical Questions, ed. J. E. McGuire and M. Tamny (Cambridge: Cambridge University Press, 1983); Molyneux, Dioptrica nova, 103 ff.

${ }^{46}$ NTV, 157-158.

47 TVV, 50.

48 Juan R. Loaiza ("Molyneux's Question in Berkeley's Theory of Vision," Theoria 32 (2017): 231-247) interprets the Molyneux problem as a mere "thought experiment".

${ }_{49}$ Codex D, folio 3 verso: see Donald S. Strong, Leonardo on the Eye (New York and London: Garland, 1979), 54.

${ }^{50}$ Kepler, "Paralipomena ad Vitellionem", in: Gesammelte Werke, vol. II, V, 3. 
performed it in a dead man's eye. ${ }^{51}$ This sort of natural camera obscura was also made and used by the German Jesuit Athanasius Kircher (in a bull's eye) and by Newton himself. ${ }^{52}$

The strange case of a man looking at the retinal images on another man's eye is a further proof that Berkeley's theory of vision - though expression of a genuine and self-standing interest in the history of optics - can hardly be conceived ontologically "neutral". ${ }^{53}$ Let us imagine a chain of eyes, one looking at the fund of another's: looking at the fund of the eye B, the eye A will see a little man on a little earth, and will judge them inverted, after a comparison with the alleged "real" man and earth outside; but if we imagine a third eye $\mathrm{C}$, looking at the fund of $\mathrm{A}$, it will be clear that the supposed external man and earth are in fact the retinal images of A. ${ }^{54}$ In Berkeley's theory of vision, the "outside" is still a real, tangible world: why should Berkeley deny such commonsensical assumption, in his technical treatises about optics? In TVV, he is quite explicit about the extent and nature of such concession: "Perhaps I think that the same Being which causeth our ideas of sight doth cause not only our ideas of touch likewise, but also all our ideas of all the other senses, with all the varieties thereof. But this, I say, is foreign to the purpose"..$^{55}$ Starting from PHK, the only real "outside" will be God, defined, at the beginning of DHP, the 'All-seeing': that is to say, the last (or the first) eye of the chain.

\section{Molyneux's Question}

Molyneux's name and philosophical reputation are mainly linked to the question posed in a letter to John Locke, written on 2 March $1693,{ }^{56}$ one

51 Christoph Scheiner, Oculus, hoc est: fundamentum opticum (Oeniponti: D. Agricola, 1619): b. I, pt. I; Descartes, “Dioptrique”, Discours V; see also his letter to Mersenne of 31 March 1638, in: Oeuvres, ed. Charles Adam and Paul Tannery (Paris: Vrin, 1964-1974): vol. VI and II, 81-103.

52 Athanasius Kircher, Physiologia kircheriana experimentalis (Amstelodami: apud Janssonio-Waesbergios, 1680): b. III, sect. IV, exp. I, 92; Isaac Newton, Opticks (London: Smith and Walford, 1704; reprint Bruxelles: Culture et Civilisation, 1966): b. I, pt. I, ax. VII.

${ }^{53}$ See Bertil Belfrage, "The Constructivism of Berkeley's New Theory of Vision", in: Minds, Ideas, and Objects. Essays on the Theory of Representation in Modern Philosophy, ed. Philip D. Cummins and Guenter Zoeller (Atascadero, California: The North American Kant Society, 1992): 167-186. The same thesis had been maintained by Geneviève Brykman, Berkeley. Philosophie et apologétique (Paris: Vrin, 1984).

${ }^{54}$ NTV, 118.

55 TVV, 29. Italics mine. The same argument is exposed in PHK, 44.

56 John Locke, The Correspondence, ed. E. S. De Beer (Oxford: Clarendon Press, 1976-1982): vol. IV, 651. 
year after the publication of Dioptrica nova. It is presented as a marginal "jocose problem", but Locke divulgates it in the second edition of his Essay (1694), thus opening one of the most important philosophical debates in the eighteenth century. It was destined to become an experimentum crucis, supposed to decide the question of the immediate or learned nature of vision: if a man born blind recovers sight, will he be able to perceive the same cube and sphere which he was used to perceive by touch?

Berkeley introduces this example in NTV, 41, after many questions asked to himself in the Notebooks, ${ }^{57}$ then, he quotes Locke's formulation of Molyneux's problem in NTV, 132; the blind man recovering sight is the living paradigm of the heterogeneity thesis: therefore, he crosses the whole NTV and concludes TVV, acting as a deus ex machina, called to say the decisive word about the discussion of magnitudes and situations of things. ${ }^{58}$

It is not possible, here, to follow that discussion in detail: $:^{59}$ too many philosophers took part in it - from Leibniz to Kant and the leading figures of the French Enlightenment such as Voltaire, La Mettrie, Condillac, Diderot, Buffon. Moreover, that outstanding epistemological debate had many important developments - due to some "mathematicians", e.g. Robert Smith and James Jurin, optic writers such as Joseph Priestley as well as the Scottish philosophers, Adam Smith, Thomas Reid and Thomas Brown, or physiologists such as Johannes Müller and Hermann von Helmholtz. At last, starting from William James, Molyneux's question was quite completely restricted to the domain of psychology.

57 See the entries 27, 32, 49, 58, 59, 97, 100, 121, 174, 183, 307, 454.

58 NTV, 79, 92 ff.; TVV, 71.

${ }^{59}$ For the detailed history of that problem in the eighteenth century, see Jean-Baptiste Merian, "Sur le problème de Molyneux", Nouveaux Mémoires des Sciences et Belles-Lettres de l'Académie Royale de Berlin (1770): 258-267; (1771): 367-389; (1772): 414-428; (1774): 439-452; (1775): 414-427; (1777): 355-368; (1779): 343-351; (1780): 399-413. See also John W. Davis, “The Molyneux Problem”, Journal of the History of Ideas 21 (1960): 392-408; Dèsirée Park, "Locke and Berkeley on the Molyneux Problem", Journal of the History of Ideas 30 (1969): 253-260; Geoffrey N. Cantor, "Weighing Light: The Role of Metaphor in Eighteenth-Century Optical Discourse", in: The Figural and the Literal. Problems of Language in the History of Science and Philosophy 1630-1800, ed. A. E. Benjamin, Geoffrey N. Cantor and J. R. R. Christie (Manchester: Manchester University Press, 1987): 124-146; Silvia Parigi, "Il problema di Molyneux", Biologica 4 (1990): 171-207; Menno Lievers, "The Molyneux Problem", Journal of the History of Philosophy 30 (1992): 399-416; Maria Teresa Monti, "La chirurgie de la cataracte. Institutions, techniques et modèles scientifiques de Brisseau à Daviel", Revue d'histoire des sciences 47 (1994): 107-127; Ralph Schumacher, "What Are the Direct Objects of Sight? Locke on the Molyneux Question", Locke Studies 3 (2003): 41-62; Silvia Parigi, "Teoria e storia del problema di Molyneux", Laboratorio dell'ISPF 1 (2004): 1-14, http:// www.ispf-lab.cnr.it/article/Saggi_Atti_291104, access 23.12.2019; Brian Glenney, “Leibniz on Molyneux's Question", History of Philosophy Quarterly 29 (2012): 247-264. 
It would be naive to expect that: 1) all the empiricists give the negative answer while all the rationalists answer positively; 2) the negative answer is consistent with every empiricist epistemology and 3) the dispute can be solved by experiment. Berkeley's naivety concerns only the third point, but he has very good reasons to think so.

The original formulation of Molyneux's problem was soon complicated by many clauses, conditions and restraints: Locke pretended that the recognition was immediate, "at first sight"; La Mettrie, Condillac and Diderot did not agree, judging such a condition unrealistic; Leibniz wanted to tell the newly sighted the names of the solids in front of him, in order to make him recognize them, while Condillac firmly refuses to give him such an advantage. Last, but not the least, Diderot demanded a philosophical training, both for the blind and the surgeon who had to observe his behavior and ask him epistemological questions; moreover, he limited the hoped recognition to plain figures - because, after Berkeley, most philosophers acknowledged the invisibility of distance, or the third dimension of space.

In 1728, Molyneux's question was exemplified by a fourteen-year old boy, operated by a famous surgeon, William Chesselden, in London: according to Chesselden's report, the boy behaved in a pure LockeanBerkeleian way. At first sight, he was not able to perceive anything; far from estimating distances, magnitudes and situations, he believed that visible objects "touched his eyes"; two months after the successful operation, he could not comprehend the pictorial perspective, and was not able to formulate correct judgments as to the magnitude of things.

Therefore, is Berkeley right when he mentions a "man somewhere near London, who had been born blind, and continued so for about twenty years" as the best judge of his theory of vision $?^{60}$ And is he right, at the very end of TVV, when he claims (as Voltaire, after him ${ }^{61}$ ) that the behavior of Chesselden's patient confirmed his theory of vision - discovered uniquely "by reasoning" and apparently "remote from common apprehension" - "by fact and experiment"? ${ }^{62}$ Berkeley's pride is far from groundless: even if Chesselden's report was vitiated by Berkeleian inclinations - as La Mettrie suspected, in his Histoire naturelle de l'âme (1745) - it seems to confirm Berkeley's boldest forecasts. Later on, up to the early 1970s, many other stories of men, women and children born

${ }^{60}$ At the end of the Appendix added to the second edition of NTV (1710); the case of the young William Jones, from Newington, near London, operated by the surgeon Roger Grant, was mentioned in the Tatler on 16 August 1709.

${ }_{61}$ See the letter to Dortous de Mairan on 1 December 1736, in Voltaire's Correspondence, ed. T. Besterman (Genève: Institut et Musée Voltaire Les Délices, 1953-65): vol. V, 339.

62 TVV, 71. 
(or early become) blind and recovering sight gave different results, nor were easily interpretable in their epistemological meaning; but Berkeley could not know it. ${ }^{63}$

Nevertheless, he has an unquestionable merit: he is the only one who gives an answer that is coherent with his philosophy of perception. Indeed, if vision can be explained by the angle of the optic axes, it should not need experience; the geometrical theory of vision maintained by "mathematicians" such as Molyneux is only compatible with nativism. Therefore, Molyneux should have given the positive answer to his own problem. ${ }^{64}$ It was the same with Locke, who maintained both the ontological distinction - first advanced by Galilei and Descartes - between primary and secondary qualities of bodies and the theory of abstract general ideas. But, if extension is an abstract idea of a primary quality, really existing in bodies, it must be introduced by sight and touch in the same way; therefore, the blind man who recovers sight should be able to recognize a cube and a sphere. ${ }^{65}$

Locke is not an optic writer; he does not propose a theory of vision: on the contrary, he admits to be quite ignorant in optics. ${ }^{66}$ Berkeley is the first "empiricist" to give a coherent answer to Molyneux's problem, even in the eighteenth-century scholars' opinion, ${ }^{67}$ because of his heterogeneity thesis and frank acknowledgement that "the humour of making one see by geometry" ${ }^{\prime \prime 8}$ deserves a sarcastic consideration.

Berkeley himself judges the extent and novelty of his own contribution to the science of optics:

${ }^{63}$ See the case of S.B., examined and told by Richard Gregory in Eye and Brain. The Psychology of Seeing (London: Weidenfeld and Nicolson, 1966); the three women studied by the Italian psychologists Maria Banissoni and Ezio Ponzo in 1968, in Rome ("Percezione strutturata e trasposizione di forme nelle prime esperienze visive di tre cieche dalla nascita operate di osteo-odonto-cheratoprotesi da Strampelli", Rivista di Psicologia 62 (1968): 515-535); and the women operated by Ackroyd in 1974 (mentioned by M. Jannerod, "Déficit visual persistant chez les aveugles-nés opérés. Données cliniques et expérimentales," L'Année Psychologique 75 (1975): 169-195).

${ }_{64}$ Colin M. Turbayne noticed this inconsistency in Molyneux's position, but failed to find the reasons thereof. See his "Berkeley and Molyneux on Retinal Images", Journal of the History of Ideas 16 (1955): 339-355 (especially 344, note 37).

65 See Michael J. Morgan, Molyneux's Question (Cambridge: Cambridge University Press, 1977); the contrary opinion is claimed by Ann Vaughan, "Is Locke's Answer to Molyneux's Question Inconsistent?", Canadian Journal of Philosophy (2018).

${ }^{66}$ Remarks upon Some of Mr. Norris's Books, Wherein he asserts P. Malebranche's Opinion of our Seeing all Things in God, in: John Locke, The Works (first edition 1823: Scientia Verlag Aalen, 1963), vol. X, 3.

67 See Merian, Sur le problème de Molyneux.

${ }^{68} \mathrm{NTV}, 53$. 
The knowledge of these connections, relations, and differences of things visible and tangible, their nature, force, and significancy hath not been duly considered by former writers in optics, and seems to have been the great desideratum in that science, which for want thereof was confused and imperfect. ${ }^{69}$

It has been cleared enough that Berkeley's criticism of the "mathematicians" did not hit a straw man. The image of a blind man perceiving objects with a couple of crossed sticks in his hands is a famous and efficacious illustration of the geometria quadam omnibus innata, by which visual perception is accomplished. In the Appendix to the second edition of NTV (1710), Berkeley explicitly quotes Descartes' Dioptrique; that image and theory might be found in Malebranche's Recherche de la vérité:70 Stoic in its origin, it had been first used by an Arabic physician, Hunain (IX century), in his Liber de oculis. ${ }^{71}$

Surely, geometry does play a role in optics in order to demonstrate theorems, to "argue and compute", "for praxis, in dioptric glasses and mirrours ${ }^{\prime \prime} ;{ }^{72}$ but not in order to judge about vision. ${ }^{73}$ Euclidean geometry is a great, deductive construction of thought, but it is completely useless while trying to explain the way in which vision is accomplished: the "true nature of vision" is far from mathematical considerations. ${ }^{74}$ There is one important exception: the invisibility of distance on which the heterogeneity thesis is largely founded rests on a geometrical axiom: "for distance being a line directed end-wise to the eye, it projects only one point in the fund of the eye, which point remains invariably the same, whether the distance be longer or shorter." ${ }^{75}$ This was a common assumption of the optic writers, in Berkeley's times, ${ }^{76}$ but nobody drew any psychological consequence from it.

The third edition of Berkeley's NTV was published in 1732, with the seven dialogues of Alciphron, an apologetic work written during his stay in Newport. Why should he feel the need to publish his first work again, and in such a company, after so many years? The answer is given at the very beginning of TVV: "the Theory of Vision affords to thinking men a new and unanswerable proof of the existence and immediate operation

69 TVV, 37.

${ }^{70}$ Descartes, "Dioptrique", Discours VI, in: Oeuvres, vol. VI; Malebranche, Recherche de la vérité, I, 9, 3.

${ }^{71}$ Ibn Is-Hāq Hunain, The Book of the Ten Treatises on the Eye, ed. M. Meyerhof (Cairo: The Government Press, 1928): 36-37.

72 TVV, 37.

73 See Geoffrey N. Cantor, "Berkeley, Reid, and the Mathematization of Mid-Eighteenth-Century Optics", Journal of the History of Ideas 38 (1977): 429-448.

${ }^{74} \mathrm{NTV}, 38,39,78 ;$ TVV, 31-32.

75 NTV, 2.

${ }^{76}$ See Tacquet, Optica, b. I, prop. I and Molyneux, Dioptrica nova, prop. 31, 113. 
of God"77 - that is to say, the doctrine of the visible world as a divine language, or "the voice of the Author of nature, which speaks to our eyes". ${ }^{78}$ Is this an optical theory? No less than Newton's doctrine of absolute space and time as sensoria Dei was a physical theory.

Does it not appear from phenomena that there is a Being incorporeal, living, intelligent, omnipresent, who in infinite space (as it were in his sensory) sees the things themselves intimately, and thoroughly perceives them, and comprehends them wholly by their immediate presence to himself? [...] And though every true step made in this philosophy brings us not immediately to the knowledge of the First Cause, yet it brings us nearer to it, and on that account is to be highly valued. ${ }^{79}$

The argument of Divine Language is the strongest and most original proof in Berkeley's apologetics, as shown in the Alciphron's fourth Dialogue. ${ }^{80}$ The metaphor of the visible, or sensible world as a divine language was born on the field of biblical hermeneutics: its author was Philo Alexandrinus (20 b. C. -45 a. C.), known to Berkeley, ${ }^{81}$ who commented on some passages in Deuteronomy (IV, 12) and Exodus (XX, 18 and 22). There is an analogy among the "voice" of God, "seen by the eyes of the soul", light and thought; the word is invisible, like the spirit. ${ }^{82}$ The divine language argument is deeply connected with Berkeley's theory of vision and immaterialism because it makes possible to establish the following theses: 1) visible objects do not exist without the mind, as "a new set of thoughts or sensations",83 2) visible ideas are not caused by tangible objects 3 ) nor are their faithful images; visible ideas may only indicate tangible objects as their signs.

Most of Berkeley's contemporaries are perfectly aware of the originality of his scientific contributions and, at the same time, capable of distinguishing them both from his metaphysical and apologetic concerns. Coming back to France from England, Voltaire took with him a new scientific conception of the world, including Berkeley's theory of vision and Newton's natural philosophy; while he always derided immaterialism,

77 TVV, 1.

${ }_{78} \mathrm{NTV}, 152$.

79 Newton, Opticks, query 29, 529.

${ }^{80}$ Berkeley himself made the point at the end of the Advertisement premised to the first two editions of Alciphron (1732).

81 As shown in Siris, 284.

${ }^{82}$ Philo Alexandrinus, "De migratione Abrahami", in: CEuvres, ed. R. Arnaldez, C. Mondésert and J. Pouilloux (Paris: CERF, 1965), vol. XIV, 47-52. See Costica Bradatan, "Berkeley and Liber Mundi", Minerva: An Internet Journal of Philosophy 3 (1999) and The Other Bishop Berkeley. An Exercise in Reenchantement (New York: Fordham University Press, 2006).

83 NTV, 41. 
as well as all other metaphysical extravagancies, he was fond of Berkeley's empiristic psychology of vision. ${ }^{84}$ Berkeley himself stated the most proper task of a scientist and a philosopher:

The work of science and speculation is to unravel our prejudices and mistakes, untwisting the closest connexions, distinguishes things that are different, instead of confused and perplexed [...] in order to obtain just and accurate notions, to speak consistently, to know even our own meaning. ${ }^{85}$

The final purpose of a scientist, a philosopher and a religious man is the same, but the intellectual paths to reach such a goal - not only worthy of a man of the Enlightenment - are different and independent one from another.

\section{Bibliography}

Alessio Franco. 1961. "Per uno studio sull'ottica del Trecento". Studi medievali 3: $444-504$.

Alhazen (Ibn al-Haytham). 1972. Opticae Thesaurus. New York-London: Johnson Reprint (first edition Basileae, 1572).

Al-Kindī. 1974. "De radiis". Archives d'histoire doctrinale et littéraire du Moyen Age 41: 139-260.

Atherton Margaret. 1990. Berkeley's Revolution in Vision. Ithaca and London: Cornell University Press.

Bacon Roger. 1897. Perspectiva. In: The Opus Maius. Oxford: Clarendon Press. Belfrage Bertil. 1992. "The Constructivism of Berkeley's New Theory of Vision". In: Minds, Ideas, and Objects. Essays on the Theory of Representation in Modern Philosophy, ed. P. D. Cummins and G. Zoeller. 167-186. Atascadero, California: The North American Kant Society.

Berkeley George. 1948-1957. The Works, ed. A. A. Luce and T. E. Jessop. London: Nelson.

Berman David. 1985. "Berkeley and the Moon Illusions”. Revue Internationale de Philosophie 39: 215-222.

Berman David (ed.). 1989. George Berkeley. Eighteenth-Century Responses. New York-London: Garland.

Bradatan Costica. 1999. "Berkeley and Liber Mundi". Minerva: An Internet Journal of Philosophy 3.

Bradatan Costica. 2006. The Other Bishop Berkeley. An Exercise in Reenchantement. New York: Fordham University Press.

84 "Éclaircissements sur la philosophie de Newton", in: Voltaire, Oeuvres complètes, ed. Louis Moland (first edition 1879; Nendeln, Liechtenstein: Kraus Reprint, 1967), vol. XXII; letters to De Mairan (1 December 1736) and Pitot (17 and 29 May 1737), in: Correspondence, vols. V and VI.

$85 \mathrm{TVV}, 35,70$. 
Brykman Geneviève. 1984. Berkeley. Philosophie et apologétique. Paris: Vrin.

Cantor Geoffrey N. 1987. "Weighing Light: The Role of Metaphor in Eighteenth-Century Optical Discourse". In: The Figural and the Literal. Problems of Language in the History of Science and Philosophy 1630-1800, ed. A. E. Benjamin, Geoffrey N. Cantor and J. R. R. Christie. 124-146. Manchester: Manchester University Press.

Cantor Geoffrey N. 1977. "Berkeley, Reid, and the Mathematization of Mid-Eighteenth-Century Optics". Journal of the History of Ideas 38: 429-448.

Charles Sébastien (ed.). 2004. Science et épistémologie selon Berkeley. Saint-Nicolas, Quebec: Les Presses de l'Université Laval.

Charleton Walter. 1966. Physiologia Epicuro-Gassendo-Charltoniana. New York and London: Johnson Reprint (first edition 1654).

Crombie Alistair C. 1986. Science, Optics and Music in Medieval and Early Modern Thought. London: Hambledon Press.

Crombie Alistair C. 1990. "Expectation, Modelling and Assent in the History of Optics: Part I. Alhazen and the Medieval Tradition". Studies in the History and Philosophy of Science 21: 605-632.

Crombie Alistair C. 1987. "La Dioptrique et Kepler". In: Le Discours et sa method, ed. N. Grimaldi and J. L. Marion. 131-144. Paris: PUF.

Crombie Alistair C. 1991. "Expectation, Modelling and Assent in the History of Optics: II. Kepler and Descartes". Studies in the History and Philosophy of Science 22: 89-115.

Daniel Steve H. (ed.). 2008. New Interpretations of Berkeley's Thought. New York: Humanity Books.

Davis John W. 1960. "The Molyneux Problem". Journal of the History of Ideas 21: 392-340.

Descartes René. 1964-1974. Dioptrique. In: Oeuvres, ed. C. Adam and P. Tannery. Paris: Vrin, vol. VI.

Eastwood Bruce S. 1986. "Alhazen, Leonardo, and Late-Medieval Speculation on the Inversion of Images in the Eye". Annals of Science 43: 413-446.

Euclides. 1573. Prospettiva. Firenze: Giunti.

Fabri Honoré. 1667. Synopsis optica. Lugduni: H. Boissat \& G. Remens.

Gassendi Pierre. 1964. Epistolae quatuor de apparente magnitudine Solis humilis et sublimis, in Opera omnia. 420-477. Stuttgart-Bad Cannstatt: Frommann (first edition 1727), vol. III.

Glenney Brian. 2012. “Leibniz on Molyneux's Question". History of Philosophy Quarterly 29: 247-264.

Gregory Richard. 1966. Eye and Brain. The Psychology of Seeing. London: Weidenfeld and Nicolson.

Grimaldi Francesco Maria. 1665. Physico-mathesis de lumine, coloribus et iride. Bononiae: ex typographia haeredis V. Benatii.

Guerlac Henri. 1969. "Bentley, Newton and Providence: The Boyle Lectures Once More". Journal of the History of Ideas 30: 307-318.

Hobbes Thomas. 1966. De corpore. In: Opera latina, ed. W. Molesworth. Londini: J. Bohn, 1839. Second Reprint Scientia Verlag Aalen, vol. I. 
Hunain Ibn Is-Hāq. 1928. The Book of the Ten Treatises on the Eye, ed. M. Meyerhof. Cairo: The Government Press.

Kepler Johannes. 1938-1998. Gesammelte Werke, ed. M. Caspar. Munchen: Beck'sche.

Kircher Athanasius. 1680. Physiologia kircheriana experimentalis. Amstelodami: apud Janssonio-Waesbergios.

Lievers Menno. 1992. “The Molyneux Problem”. Journal of the History of Philosophy 30: 399-416.

Lindberg David C. 1968. "The Theory of Pinhole Images from Antiquity to the Thirteenth Century". Archive for the History of the Exact Sciences 5: 154-176.

Lindberg David C. (ed.). 1970. John Pecham and the Science of Optics. Perspectiva communis. Madison, Milwaukee and London: The University of Wisconsin Press.

Lindberg David C. 1976. Theories of Vision from Al-Kindi to Kepler. Chicago and London: University of Chicago Press.

Lindberg David C. 1978. "The Science of Optics". In: Science in the Middle Ages, ed. D. C. Lindberg. 338-368. Chicago and London: University of Chicago Press.

Lindberg David C. 1983. Studies in the History of Medieval Optics. London: Variorum Reprints.

Lindberg David C. 1987. "Roger Bacon and the Origin of Perspectiva in the West". In: Mathematics and Its Applications to Science and Natural Philosophy in the Middle Ages. Edited by E. Grant and J. E. Murdoch. 249-268. Cambridge: Cambridge University Press.

Loaiza Juan R. 217. “Molyneux's Question in Berkeley's Theory of Vision". Theoria 32: 231-247.

Locke John. 1963. The Works. Aalen: Scientia Verlag Aalen, first edition 1823.

Locke John. 1975. An Essay concerning Human Understanding, ed. P. H. Nidditch. Oxford: Clarendon Press.

Locke John. 1976-1782. The Correspondence, ed. E. S. De Beer. Oxford: Clarendon Press.

Malebranche Nicolas. 1962-1970. Oeuvres, ed. G. Rodis-Lewis, A. Robinet et al. Paris: Vrin.

Merian Jean-Baptiste. 1770-1780. "Sur le problème de Molyneux". Nouveaux Mémoires des Sciences et Belles-Lettres de l'Académie Royale de Berlin (1770): 258-267; (1771): 367-389; (1772): 414-428; (1774): 439-452; (1775): 414-427; (1777): 355-368; (1779): 343-351; (1780): 399-413.

Molyneux William. 1687. "Concerning the Apparent Magnitude of the Sun and Moon, or the Apparent Distance of two Stars, when nigh the Horizon, and when Higher Elevated". Philosophical Transactions of the Royal Society of London 187: 314-323.

Molyneux William. 1692. Dioptrica Nova. London: B. Tooke.

Morgan Michael J. 1977. Molyneux's Question. Cambridge: Cambridge University Press. 
Newton Isaac. 1966. Opticks. Bruxelles: Culture et Civilisation, first edition 1704.

Newton Isaac. 1958. Isaac Newton's Papers \& Letters on Natural Philosophy, ed. I. B. Cohen. Cambridge, Mass.: Harvard University Press.

Newton Isaac. 1983. Certain Philosophical Questions, ed. J. E. McGuire and M. Tamny. Cambridge: Cambridge University Press.

Nicolson Marjorie. 1962. Science and Imagination. Ithaca-New York: Great Seals Book.

Parigi Silvia. 1987. "George Berkeley e l'illusione lunare". Rivista di storia della scienza 4: 51-60.

Parigi Silvia. 1980. “La 'quaestio' di Barrow: un'aporia della visione tramite lenti". Nuncius 3: 65-69.

Parigi Silvia. 1989. “L'occhio e la camera oscura: storia dell'abbandono di una metafora". Iride 3: 91-109.

Parigi Silvia. 1990. "Il problema di Molyneux". Biologica 4: 171-207.

Parigi Silvia. 1993. "I filosofi e il microscopio; da Descartes a Berkeley". Rivista di storia della scienza 1: 155-172.

Parigi Silvia. 1995. Il mondo visibile. George Berkeley e la 'perspectiva'. Firenze: Olschki.

Parigi Silvia. 2004. "Teoria e storia del problema di Molyneux". Laboratorio dell'ISPF 1: 1-14. http://www.ispf-lab.cnr.it/article/Saggi_Atti_291104. Access 23.12.2019.

Parigi Silvia. 2010. "Siris and the Renaissance: Some Overlooked Berkeleian Sources". Revue philosophique de la France et de l'étranger 1: 151-162.

Parigi Silvia. 2010. "'Scire per causas' versus 'scire per signa': George Berkeley and Scientific Explanation in Siris". In: George Berkeley. Religion and Science in the Age of Enlightenment. Edited by Silvia Parigi. 107-119. Dordrecht: Springer.

Park Dèsirée. 1969. "Locke and Berkeley on the Molyneux Problem”. Journal of the History of Ideas 30: 253-260.

Pastore Nicholas. 1971. Selective History of Theories of Visual Perception 1650-1950. New York-London: Oxford University Press.

Philo Alexandrinus. 1965. De migratione Abrahami. In: CEuvres, ed. R. Arnaldez, C. Mondésert and J. Pouilloux. 47-52. Paris: CERF, vol. XIV.

Plotinus. 2002. Enneadi, ed. Giovanni Reale. Milano: Mondadori.

Ptolemaeus Claudius. 1515. Almagestum. Venetiis: P. Lichtenstein.

Ptolemaeu Claudius. 1855. Optica. Torino: Paravia.

Regis Pierre Sylvain. 1691. Système de philosophie. Lugduni: Anisson, Posuel \& Rigaud.

Revue d'histoire des sciences. 2007. 1.

Robles José Antonio. 2004. "Philosophie naturelle et religion: les cas de Newton, Boyle et Berkeley". In: Charles Sébastien (ed.). 2004. Science et épistémologie selon Berkeley. Saint-Nicolas, Quebec: Les Presses de l'Université Laval.

Rohault Jacques. 1740. Traité de physique. Venetiis: F. Pitteri, first edition 1671. 
Sabra A. I. 1967. Theories of Light from Descartes to Newton. London: Oldbourne.

Scheiner Christoph. 1619. Oculus, hoc est: fundamentum opticum. Oeniponti: D. Agricola.

Schumacher Ralph. 2003. "What Are the Direct Objects of Sight? Locke on the Molyneux Question". Locke Studies 3: 41-62.

Strong Donald S. 1979. Leonardo on the Eye. New York and London: Garland. Tacquet André. 1707. Cataoptrica. In: Opera matematica. Antuerpiae: I. Meursium.

Turbayne Colin M. 1955. "Berkeley and Molyneux on Retinal Images". Journal of the History of Ideas 16: 339-355.

Voltaire (Arouet François Marie). 1967. Oeuvres completes, ed. L. Moland. Nendeln. Liechtenstein: Kraus Reprint.

Voltaire (Arouet François Marie). 1953-1965. Correspondence, ed. T. Besterman. Genève: Institut et Musée Voltaire Les Délices.

Wallis John. 1687. "The Sentiments of the Reverend and Learned Dr. John Wallis upon the Aforesaid Appearance, communicated in a Letter to the Publisher". Philosophical Transactions of the Royal Society of London 187: 323-329.

Wilson Catherine. 1988. "Visual Surface and Visual Symbol: the Microscope and the Occult in Early Modern Science". Journal of the History of Ideas 4: 85-108.

Witelo. 1535. De natura, ratione et proiectione radiorum visus, luminum, colorum atque formarum, quam vulgo perspectivam vocant. Norimbergae: I. Petreium.

\section{Summary}

This essay offers a wide historical overview of the various, composite and sometimes unexpected sources of Berkeley's theory of vision. It offers a commentary of the main questions faced in Berkeley's NTV, highlights the authentic and genuine scientific character of Berkeley's theory of vision, and shows some important links among optics, metaphysics and theology in Berkeley's thought.

Keywords: perspectiva, vision, distance, magnitude, Barrow's question, Moon illusion, minima visibilia and tangibilia, Molyneux's question, divine language, retinal images 